AperTO - Archivio Istituzionale Open Access dell'Università di Torino

\title{
Activity of benzothiadiazole on chrysanthemum yellows phytoplasma ('Candidatus Phytoplasma asteris') infection in daisy plants
}

\section{This is the author's manuscript}

Original Citation:

Availability:

This version is available http://hdl.handle.net/2318/132164

since 2016-01-28T16:33:39Z

Published version:

DOI:10.1016/j.cropro.2010.03.011

Terms of use:

Open Access

Anyone can freely access the full text of works made available as "Open Access". Works made available under a Creative Commons license can be used according to the terms and conditions of said license. Use of all other works requires consent of the right holder (author or publisher) if not exempted from copyright protection by the applicable law. 


\section{(4) \\ UNIVERSITÀ DEGLI STUDI DI TORINO}

This Accepted Author Manuscript (AAM) is copyrighted and published by Elsevier. It is posted here by agreement between Elsevier and the University of Turin. Changes resulting from the publishing process - such as editing, corrections, structural formatting, and other quality control mechanisms - may not be reflected in this version of the text. The definitive version of the text was subsequently published in Crop Protection, 29(10): 1094-1099, 2010 - http://dx.doi.org/10.1016/j.cropro.2010.03.011

You may download, copy and otherwise use the AAM for non-commercial purposes provided that your license is limited by the following restrictions:

(1) You may use this AAM for non-commercial purposes only under the terms of the CC-BY-NC-ND license.

(2) The integrity of the work and identification of the author, copyright owner, and publisher must be preserved in any copy.

(3) You must attribute this AAM in the following format: Creative Commons BY-NC-ND license (http://creativecommons.org/licenses/by-nc-nd/4.0/deed.en), [+ Digital Object Identifier link to the published journal article on Elsevier's ScienceDirect ${ }^{\circledR}$ platform $]$ 
Activity of benzothiadiazole on chrysanthemum yellows phytoplasma ('Candidatus Phytoplasma asteris') infection in daisy plants

${ }^{\mathrm{b}}$ Istituto di Virologia Vegetale, CNR, Strada delle Cacce, 73, 10135 Torino, Italy

\section{Abstract}

A commercial preparation of the plant resistance elicitor benzothiadiazole (BTH) (Bion, Syngenta Crop Protection) was tested for its capacity to induce systemic resistance against chrysanthemum yellow phytoplasma (CYP) infection in the Chrysanthemum carinatum plant. Following one 2.4 mM BTH application, plants were exposed to CYP-infective Macrosteles quadripunctulatus leafhoppers. Symptom development and phytoplasma multiplication in the test plants were measured over time. BTH application delayed symptom development and phytoplasma multiplication in treated plants compared with the control ones. CYP titre and symptom severity were significantly lower for the first two weeks post-inoculation in treated plants compared with the control ones, suggesting that systemic acquired resistance (SAR) induced by BTH in $C$. carinatum is temporary. Higher concentrations of BTH resulted in phytotoxic effects involving the whitening of apical leaves. BTH application was ineffective in reducing the transmission efficiency of CYP by its leafhopper vector. Actually, in both single and group transmission tests, the proportion of infected plants was similar among BTH-treated and untreated plants. The survival of $M$. quadripunctulatus was unaffected by feeding on BTH-treated daisy plants. Moreover, when leafhoppers were allowed to choose between treated and untreated plants, they showed no preference. We conclude that SAR induced in daisy plants by BTH has no detrimental effects on the vector leafhopper. If the activity of BTH against phytoplasmas is confirmed also on other 
phytoplasma/host-plant associations, BTH applications might be included in new, more environmentally friendly, integrated management strategies of phytoplasmoses.

\section{Keywords}

Benzothiadiazole, resistance elicitor, systemic acquired resistance, chrysanthemum yellows phytoplasma, Macrosteles quadripunctulatus

\section{Introduction}

Phytoplasmas are wall-less pathogenic bacteria belonging to the class Mollicutes that are associated with economically important diseases of fruit trees (pome fruit, stone fruit, coconut and grapes among others), vegetables (lettuce, potato, tomato, etc.), ornamentals (herbaceous, trees and shrubs) and weeds (Seemüller et al., 1998; Bertaccini et al., 2007). They are phloem-limited pathogens that cause several different symptoms such as yellowing, stunting, proliferation, virescence, phyllody and general decline. Phytoplasmas are transmitted in a persistent, propagative manner by Hemipteran phloem-sucking insects in the Cicadellidae, Cixiidae, Derbidae, Delphacidae and Psyllidae families (Weintraub and Beanland, 2006).

The control of phytoplasma diseases is difficult and relies mainly on insecticide treatments against vector insects and the planting of healthy propagation material. Insecticides can be effective in suppressing the vector population but only neonicotinoids actively prevent the transmission from infectious insects visiting the crop (Saracco et al., 2008). Large scale use of insecticides (in preventing the spread of phytoplasma diseases) has a negative impact on non-target arthropods, especially mites (Waetermeulen et al., 1999) and, possibly, on pollinators (Vorwohl, 1977), and represents a potential threat to human health. Planting phytoplasma-free stocks is advisable, but control of vector populations is still required to prevent transmission during the vegetative season (Morone et al., 2007). Traditional vector exclusion methods, such as the use of insect-proof nets, 
though very effective if properly secured in place (Walsh et al., 2006), can be applied in protected crops but not open field conditions.

Systemic acquired resistance (SAR) is an inducible resistance mechanism in plants that provides resistance against plant pathogens. The treatment of plants with various agents (e.g., virulent or avirulent pathogens, nonpathogens, cell wall fragments, plant extracts and synthetic chemicals) can lead to the induction of resistance to subsequent pathogen attack. SAR by plant activators provided interesting results in the control of a broad spectrum of pathogens, such as bacteria, fungi and viruses (Oostendorp et al., 2001; Vallad and Goodman, 2004). In the vast majority of cases, SAR depends on the early increase of the endogenously synthesized signal salicylic acid and it is correlated with the immediate expression of a specific set of genes which includes those coding for pathogenesis-related-proteins (PR) (Pieterse and Van Loon, 2007). Several PR proteins (e.g. $\beta-1,3$ glucanases, chitinases, osmotin) possess anti-microbial activity and are thought to contribute to the state of resistance together with other PR (e.g. hydroxyproline rich glycoproteins, callose) that are important in cell wall structure. Among the synthetic inducers of plant disease resistance, acibenzolar-S-methyl, a benzothiadiazole (BTH), is a well-studied compound (Schurter et al., 1987; Friedrich et al., 1996) that has extensively been shown to induce SAR in many crops, such as monocots, solanaceous, leguminous and fruit trees (Gorlach et al., 1996; Buonaurio et al., 2002; Dann and Deverall, 1995; Ishii et al., 1999).

Bressan and Purcell (2005) reported a significant effect of BTH in reducing X-disease phytoplasma transmission to Arabidopsis thaliana (L.) Heynh. by the leafhopper Colladonus montanus (Van Duzee), whereas Romanazzi et al. (2009) noticed a higher recovery rate from bois noir phytoplasma in grapevines treated with BTH and other resistance elicitors. Conflicting information is available on the effect of BTH on phytophagous insects. In most cases, the salicylic acid pathway involved in SAR development has only negligible effects on phytophagous insects (Inbar et al., 2001; Bi et al., 1997), but for some phloem feeders reduced fecundity and increased mortality have been reported following feeding on BTH-treated plants (Bressan and Purcell, 2005; Boughton et al., 2006). 
The aim of this study was to investigate the effect of benzo-(1,2,3)-thiadiazole-7-carbothioic acid Smethyl ester (BTH), on the transmission of chrysanthemum yellows phytoplasma (CYP) to daisy plants under controlled conditions. The association of Chrysanthemum carinatum (Schousboe)CYP-Macrosteles quadripunctulatus (Kirschbaum) represents an optimal model system because of i) the short incubation of the phytoplasma in the plant and short latency in the vector, ii) rapid and obvious symptom development, iii) extremely high transmission efficiency, iv) the polyvoltine vector that can be easily reared throughout the year and v) the availability of detection and quantification tools for the phytoplasma (Marzachì and Bosco, 2005). CYP is a strain of the 'Candidatus Phytoplasma asteris' phytoplasma (16Sr-IB), which infects a variety of dicotyledonous plants and is transmitted with different efficiencies by several species of leafhoppers (Bosco et al., 2007). The activity of BTH on CYP disease was measured through the analysis of disease severity and the quantification of CYP cells in infected, treated and untreated plants, by quantitative real time PCR analysis (qRT-PCR).

\section{Materials and methods}

\section{Plants and BTH treatments}

114 C. carinatum plants were grown from seed, individually transplanted in $8 \times 8 \mathrm{~cm}$ pots and 115 maintained in a greenhouse $\left(20-25^{\circ} \mathrm{C}\right.$, photoperiod L16:D8). One month after sowing (when they were 5-6 cm high), plants were sprayed with BTH solutions (Bion WG50, 50\% active ingredient,

117 a.i., Syngenta Crop Protection) diluted with sterile water and applied as a foliar treatment to a run118 off point. Control plants were sprayed with water. After the treatment, plants were maintained in a 119 greenhouse under the conditions described above. Three different concentrations of BTH were 120 evaluated in preliminary assays, $1.2,2.4$ and $4.8 \mathrm{mM}$, to determine the concentration providing the 121 best results. The preliminary experiment was carried out twice. Three further experiments were then performed using the $2.4 \mathrm{mM}$ concentration only. In each experiment, 10 plants per treatment were 
124 plants (CYP), control plants untreated and unexposed to CYP (C) and BTH-treated and CYP125 infected plants (BTH-CYP).

Phytoplasma and vector insect

128 The 'Candidatus Phytoplasma asteris' (strain 16Sr-IB), originally isolated from Argyranthemum 129 frutescens (L.) Schultz-Bip plants in Liguria (Italy) (Conti and Mela, 1987), was maintained on the 130 daisy (C. carinatum ) by vector transmission.

131 Healthy colonies of $M$. quadripunctulatus were reared on potted oat plants inside Plexiglas and 132 nylon cages in growth chambers at $25^{\circ} \mathrm{C}$ (photoperiod L16:D8) and checked by nested PCR using 133 the R16F2/R2 followed by R16F1/R1 (I) primers (Lee et al., 1993, 1994) to verify phytoplasma 134 absence.

135 For transmission experiments, the third- to fifth-instar nymphs were fed for one week of the acquisition access period (AAP) on CYP-infected plants, transferred onto healthy oat plants for two weeks to complete the latency period (LP) and then transferred individually to 10 daisy plants, confined inside glass cylinders, for each elicitor and control treatment, for an inoculation access 139 period (IAP) of three days. Males and females of $M$. quadripunctulatus were used in the 140 transmission experiments since both genders proved to transmit CYP with $100 \%$ efficiency under 141 the experimental conditions described above (Bosco et al., 2007). Test plants were exposed to vectors one week after BTH treatment (about five weeks after sowing). Insects were then removed and plants were drench-treated with the systemic insecticide thiamethoxam (Actara, Syngenta Crop

144 Protection), $7 \mathrm{mg}$ a.i. per plant, to kill nymphs hatched from eggs eventually laid by vector females. 145 Test plants were maintained in the greenhouse for about one month. Daisy plants treated with water 146 and exposed to vectors were used as transmission controls. Treated plants not exposed to vectors 147 were used as treatment controls. Apical leaves of five daisy test plants were sampled at six, 11, 13 148 and 20 days after the end of the inoculation (dpi) from the same test plants. Total DNA was 
extracted and CYP DNA quantified by qRT-PCR. The quantification of phytoplasma cells was not performed in the two preliminary experiments where only symptom severity was evaluated.

\section{Choice test}

In a choice experiment, eight healthy daisy plants $(5-6 \mathrm{~cm}$ high) were sprayed to the run-off point with $2.4 \mathrm{mM} \mathrm{BTH}$ and eight healthy daisy plants were sprayed with water as a control. After one week, treated and untreated plants were set interspersed inside a Plexiglas and nylon cage $(80 \times 80$ $\times 60 \mathrm{~cm}$ ). Following an AAP of seven days on untreated source plants and an LP on oat as described above, 10 infective adult vectors were introduced into the cage for an IAP of three days; vectors were free to fly and feed on all the plants. The cage was maintained in a climatic chamber at $25^{\circ} \mathrm{C}$ (photoperiod L16:D8). At the end of the IAP, insects were counted and removed. Test plants were treated with insecticide and transferred to the greenhouse for about one month or until the appearance of symptoms. Infection of the plants was established on the basis of symptoms. The experiment was performed twice.

No-choice test

165 Sixteen daisy plants (5-6 cm high) were treated with $2.4 \mathrm{mM} \mathrm{BTH}$ to the run-off point and 16 166 plants were treated with water as a control. After one week, BTH-treated and control plants were separately placed inside two Plexiglas and nylon cages $(80 \times 80 \times 60 \mathrm{~cm})$. Following an AAP on CYP source plants of seven days and an LP on oat as described, 10 infective adult vectors were 169 introduced into each cage for an IAP of three days on the test plants; vectors were free to fly and 170 feed on all plants. The cages were maintained in a climatic chamber at $25^{\circ} \mathrm{C}$ (photoperiod L16:D8). 171 At the end of the IAP, insects were counted and removed. Plants were treated with insecticides and 172 transferred to the greenhouse for about one month. Infection of the plants was established on the 173 basis of symptoms. The experiment was performed twice. 
The severity of the symptoms of test plants was evaluated three times a week between 11 and 32 dpi, and plants were classified into five classes of severity: $0=$ no symptoms, $1=$ yellowing of the apex, 2 = yellowing and distortion of the apex, $3=$ apex growth stunt, $4=$ severe yellowing and dwarfing of the whole plant and $5=$ plant death.

\section{Phytoplasma concentration: DNA extraction and $q R T-P C R$}

The activity of BTH on CYP was quantified by assessing phytoplasma titre in five plants from each treatment. Total DNA was extracted from CYP-infected daisy leaves $(0.1 \mathrm{~g})$ using the PureLink Plant Total DNA Purification Kit (Invitrogen, Carlsbad, CA, USA) according to the manufacturer's protocol and eluted in $50 \mu \mathrm{L}$ of kit elution buffer. Total DNA was extracted from healthy daisy plants using the same protocol. The concentration of DNA extracts from CYP-infected daisies and healthy controls was measured with a NanoDrop 1000 Spectrophotometer (Thermo Fisher Scientific, Wilmington, DE, USA). Diluted samples ( $1 \mathrm{ng} / \mu \mathrm{L}$ in sterile double-distilled water) were analysed in triplicate in qRT-PCR assays. CYP DNA in each sample was measured as the number of CYP cells per ng of plant DNA (Marzachì and Bosco, 2005).

The absolute quantification of CYP was achieved by comparing the CTs of the samples with those of three dilutions of a plasmid, pOP74, containing the phytoplasma 16S rDNA target sequence. One femtogram of pOP74 contained 194 molecules of plasmid, with each containing a single copy of the CYP 16S rDNA gene. Because this gene is present in two copies in phytoplasma genomes, one femtogram of pOP74 corresponded to 97 CYP cells (Marzachì and Bosco, 2005). The absolute quantification of daisy plant DNA was achieved by comparing the CTs of the samples with those of four dilutions of healthy daisy DNA. All samples were run on triplicate.

\section{Data analysis}


Symptom evaluation. At each rating date, the means and standard errors of severity class were

201 calculated for treated and control plants and pairwise $t$ tests were performed to compare symptom severity between treatments, according to Alexander et al. (1993). Results from the transmission experiments (positive/negative plants) were analysed using the $\chi^{2}$ test.

Phytoplasma concentration. For the analyses, the concentration of CYP in each plant was expressed as the difference between the logarithm concentration of CYP and that of daisy plant DNAs. Finally, CYP concentration was expressed as cell number per ng of plant DNA. After comparing the phytoplasma titre measured at each sampling date in the three quantification experiments, data were pooled since they did not differ significantly among experiments. To compare phytoplasma titre measured at different dpi in BTH-treated and control plants, a two-way ANOVA for date and treatment was performed. The ANOVA, $t$ test and $\chi^{2}$ test were performed using Jandel SigmaPlot 21111.0 (Systat Software, Inc, San Jose, CA, USA).

\section{Results}

\section{Transmission results and symptom severity}

215 Following inoculation with CYP-infective leafhoppers, 16 out of 20 plants treated with $1.2 \mathrm{mM}$ 216 BTH, 14 out of 20 plants treated with $2.4 \mathrm{mM} \mathrm{BTH}$ and 19 out of 20 plants treated with $4.8 \mathrm{mM}$ 217 BTH became infected. Among the untreated control plants, 16 out of 20 became infected. The 218 proportion of infected/uninfected plants between BTH-treated and untreated plants did not differ 219 significantly. Moreover, the $4.8 \mathrm{mM}$ BTH treatment caused phytotoxic effects on some plants, 220 which exhibited an unusual whitening of the apical leaves and inhibited plant growth compared 221 with the controls. These effects lasted from 14 dpi until the end of the experiment. Symptom severity recorded from 11 to 32 dpi on plants treated with different BTH concentrations and untreated infected control plants is shown in Fig. 1. Consequently, in the following experiments the of 30 untreated plants became infected in the remaining experiments. Overall, following inoculation 
with CYP-infective leafhoppers, 39 out of 50 plants treated with $2.4 \mathrm{mM} \mathrm{BTH}$ and 45 out of 50 untreated plants became infected, but the difference was not significant $\left(\chi^{2}=1.860 ; P=0.173\right)$. The results of the five experiment repeats with $2.4 \mathrm{mM} \mathrm{BTH}$ are summarised in Fig. 2. Symptom severity recorded from 11 to 32 dpi on 50 plants treated with $2.4 \mathrm{mM} \mathrm{BTH}$ and the 50 untreated 230 infected control plants is shown in Fig. 3. Overall, test plants treated with $2.4 \mathrm{mM}$ BTH showed 231 lower symptom severity, but this difference was significant only at 11,14 and $17 \mathrm{dpi}(P=0.013, P$ $232=0.001$ and $P=0.005$, respectively) (Fig. 3).

233 In one experiment, two $2.4 \mathrm{mM}$ BTH-treated plants showed clear symptoms until 31 dpi (class 3 234 symptoms), but afterwards the symptoms completely disappeared. The recovery of these plants was 235 checked by nested PCR using the R16F2/R2 followed by R16F1/R1 (I) primers (Lee et al., 1993, 236 1994) and they proved to be phytoplasma-negative.

Choice test

239 When infective leafhoppers were allowed to feed freely on $2.4 \mathrm{mM} \mathrm{BTH-treated} \mathrm{and} \mathrm{control} \mathrm{plants,}$ 24014 out of 32 BTH-treated plants and 12 out of 32 control plants became infected; however, the 241 difference was not significant. Eight and nine live insects were counted at the end of the two repeats 242 of the experiment.

No-choice test

245 When infective leafhoppers were allowed to feed separately on 16 BTH-treated or control plants, 21 246 out of 32 control plants and 23 out of 32 BTH-treated plants became infected; however, the 247 difference was not significant. Eight and nine live insects were counted at the end of the two repeats 248 of the experiment for the treated plants, and seven and nine live insects were counted at the end of 249 the two repeats of the experiment for the untreated plants. 
Phytoplasma titre in plants treated with $2.4 \mathrm{mM} \mathrm{BTH}$ was significantly lower than that of control 253 plants $(P<0.001)$. Phytoplasma titre significantly increased over time from 6 to 20 dpi $(P<0.001)$ in treated and control plants. There was no significant interaction between date and treatment. Mean numbers of CYP cells per ng of plant DNA in treated and control plants are shown in Table 1.

\section{Discussion}

BTH has been largely employed to activate SAR for the control of plant disease caused by several pathogenic fungi, bacteria and viruses. However, little is known about its activity towards phytoplasma diseases and, to our knowledge, only two reports are available on the activity of this chemical on phytoplasmas: one towards X-disease phytoplasma transmission to A. thaliana studied under controlled conditions (Bressan and Purcell, 2005), and the other on grapevine bois noir phytoplasma (Stolbur phytoplasma or 'Candidatus Phytoplasma solani') under field conditions (Romanazzi et al., 2009). Our study demonstrated for the first time that phytoplasma multiplication and symptom development are partially hampered in the host plant by BTH treatment. CYP symptom development and multiplication were both delayed 13-17 dpi under our experimental conditions. Later, BTH elicitation against phytoplasma infection seemed to be lost. This suggests that BTH elicitation against CYP is temporary and tends to disappear over time. In our experiments, we treated test plants only once, one week before insect transmission, and we cannot exclude that a further application might have delayed phytoplasma multiplication and symptom severity later in the infection process. Actually, Buonaurio et al. (2002) found that, under field conditions, the highest efficacy of this elicitor against Xanthomonas campestris pv. vesicatoria (Doidge) Dye was obtained by spraying pepper plants 6-7 times every 8-12 days. YuHong et al. (2006) reported that the induced resistance against downy mildew in cucumber plants persisted for 15 days. It is known that BTH-elicited resistance lasts longer in monocots than dicots (Oostendorp et al., 2001; Vallad and Goodman, 2004), and that the temporary activity of BTH we recorded in CYP-infected daisy 
plants is consistent with this. Interestingly, BTH application was effective in delaying CYP

278 multiplication and symptom development but not in reducing transmission efficiency of CYP by its leafhopper vector. Actually, in both single and group transmission tests, the proportion of infected plants was similar among BTH-treated and untreated plants. This result is consistent with the fact that the survival of $M$. quadripunctulatus was unaffected by the feeding period on daisy BTHtreated plants. On the contrary, the reduced survival of $C$. montanus on A. thaliana BTH-treated 283 plants suggests that SAR in this plant might have some detrimental effect on this leafhopper, inhibiting vector feeding and thereby phytoplasma transmission efficiency (Bressan and Purcell, 2005). Considering that the different pathways might not be similarly regulated in all systems (Maleck and Dietrich, 1999), it seems that the systemic response induced by Bion on insect herbivores could vary among plant and insect species. Our results are, therefore, consistent with other studies reporting that SAR had a slight or negligible effect on phytophagous insects such as some cotton pests or the silverleaf whitefly (Inbar et al., 2001; Bi et al., 1997). Other studies noticed some resistance against the silverleaf whitefly induced by BTH. The resistance consists in nymph number reduction and in a delay in insect development (Nombela et al., 2005; Muniz et al., 2009).

We recorded lower phytoplasma multiplication in BTH-elicited plants. Similarly, SAR induced by BTH or plant growth-promoting rhizobacteria was found to suppress the replication of cucumber mosaic virus (Anfoka, 2000, Raupach et al., 1995). Moreover, our study also showed that BTHtreated plants had less severe symptoms. Therefore, we suggest that the lower phytoplasma titre in the elicited plants is directly correlated to the delay in symptom expression. These results suggest that BTH could induce resistance with an indirect or direct mechanism. An indirect activity, through the activation of SAR, is more likely to occur because BTH is known to induce the expression of SAR genes (Friedrich et al., 1996; Gorlach et al., 1996; Lawton et al., 1996). Until now, Bion is 301 known to activate a plant's defence system only and not directly on the pathogen. A direct effect on phytoplasma multiplication cannot be excluded a priori. Because the chemical persistence of BTH 
303 does not exceed five days (Buonaurio et al., 2002), whereas we recorded phytoplasma 304 multiplication and symptom expression for up to two weeks, an indirect mechanism of action is 305 suggested.

306 We observed that, under our conditions, BTH displayed some phytotoxic effects when applied at a $3074.8 \mathrm{mM}$ concentration. This is unsurprising given that several authors reported phytotoxic effects at 308 different concentrations in different crop species/cultivars (Iriti and Faoro, 2003; Amzalek and 309 Cohen, 2007; Perez et al., 2003; Bigirimana and Höfte, 2002).

310 Two daisy plants treated with $2.4 \mathrm{mM} \mathrm{BTH}$ and infected by CYP following insect transmission 311 completely recovered from the disease after one month. This finding, although not repetitive, is 312 peculiar because in our experience we have never observed such a recovery. This complete 313 recovery involved the disappearance of CY phytoplasmas, as demonstrated by nested PCR assays, 314 and was likely to be because of the BTH application. A similar recovery-inducing effect has been 315 reported for BTH-treated grapevines (Romanazzi et al., 2009).

316 The practical application of resistance elicitors towards phytoplasma diseases is in its infancy but, 317 given the difficulties in controlling phytoplasma diseases (relying mainly on insecticide treatments 318 against the vectors and roguing infected plants), the use of BTH is a promising new tool that could 319 be implemented in an integrated pest management strategy. Main limitations are represented by the 320 need of repeated applications and by the only partial tolerance that may be of low agronomical 321 interest, depending on the crop. In the light of avoiding repeated applications some biotic elicitors, 322 mycorrhizal fungi and rhizobacteria, seem to be promising (D'Amelio et al., 2007). Our results, 323 obtained on an experimental model pathosystem, should now be tentatively transferred to more 324 important crop systems (e.g., vineyards and orchards) before designing new integrated management 325 strategies that will eventually allow the reduction of insecticide applications for a more 326 environmentally friendly control of phytoplasmoses. 
This work has been supported by the Piedmont Region within the project "Valutazione dell'azione

330 di microrganismi rizosferici ed elicitori di resistenza sull'infezione da fitoplasmi in un sistema 331 modello (CIPE 2006)".

\section{References}

334 Alexander, D., Goodman, R.M., Gut-Rella, M., Glascock, C., Weymann, K., Friedrich, L., Maddox, D., Ahl-Goy, P., Luntz, T., Wad, E., Ryals, J., 1993. Increased tolerance to two oomycete pathogens in transgenic tobacco expressing pathogenesis-related protein 1a. Proc. Natl. Acad. Sci. USA 90, 7327-7331.

Amzalek, E., Cohen, Y., 2007. Comparative efficacy of systemic acquired resistance-inducing compounds against rust infection in sunflower plants. Phytopathology 97, 179-186.

Anfoka, G.H., 2000. Benzo-(1,2,3)-thiadiazole-7-carbothioic acid S-methyl ester induces systemic resistance in tomato (Lycopersicon esculentum Mill. cv. Volledung) to cucumber mosaic virus. Crop Protection 19, 401-405.

Bertaccini, A., 2007. Phytoplasmas: diversity, taxonomy and epidemiology. Frontiers in Bioscience

Bigirimana, J., Höfte, M., 2002. Induction of systemic resistance to Colletotrichum lindemuthianum $12,673-689$.

Bi, J.L., Murphy, J.B., Felton, G.W., 1997. Does salicylic acid act as a signal in cotton for induced resistance to Helicoverpa zea?. J. Chem. Ecol. 23, 1805-1818.

352 Boughton, A.J., Hoover, K., Felton, G.W., 2006. Impact of chemical elicitor applications on greenhouse tomato plants and population growth of the green peach aphid, Myzus persicae. Entomol. Exp. Appl. 120, 175-188. 
Bressan A., Purcell A.H., 2005. Effect of benzothiadiazole on transmission of X-disease phytoplasma by the vector Colladonus montanus to Arabidopsis thaliana, a new experimental host plant. Plant Dis. 89, 1121-1124.

Buonaurio, R., Scarponi, L., Ferrara, M., Sidoti, P., Bertona, P., 2002. Induction of systemic acquired resistance in pepper plants by acibenzolar-S-methyl against bacterial spot disease. Eur. J. Plant Pathol. 108, 41-49.

Conti, M., Mela, L., 1987. Il giallume della margherita (Chrysanthemum frutescens), micoplasmosi

D'Amelio R., Massa N., Gamalero E., D'Agostino G., Sampo S., Berta G., Faoro F., Iriti M., Bosco D., Marzachi C., 2007. Preliminary results on the evaluation of the effects of elicitors of plant resistance on chrysanthemum yellows phytoplasma infection. Bull. Insectol. 60, 317-318.

Dann, E.K., Deverall, B.J., 1995. Effectiveness of systemic resistance in bean against foliar and soil-borne pathogens as induced by biological and chemical means. Plant Pathol. 44, 458466.

Friedrich, L., Lawton, K., Ruess, W., Masner, P., Specker, N., Rella, M.G., Meier, B., Dincher, S., Staub, T., Uknes, S., Metraux, J.P., Kessmann, H., Ryals, J., 1996. A benzothiadiazole derivative induces systemic acquired resistance in tobacco. Plant J. 10, 61-70.

Görlach, J., Volrath, S., Knaufbeiter, G., Hengy, G., Beckhove, U., Kogel, K.H., Oostendorp, M., Staub, T., Ward, E., Kessmann, H., Ryals, J., 1996. Benzothiadiazole, a novel class of inducers of systemic acquired resistance, activates gene expression and disease resistance in wheat. Plant Cell 8, 629-643.

Inbar, M., Doostdar, H., Gerling, D., Mayer, R.T., 2001. Induction of systemic acquired resistance in cotton by BTH has a negligible effect on phytophagous insects. Entomol.. Exp.. Appl. 99, $65-70$.

Iriti, M., Faoro, F., 2003. Benzothiadiazole (BTH) induces cell-death independent resistance in Phaseolus vulgaris against Uromyces appendiculatus. J. Phytopathol. 151, 171-180. 
Ishii, H., Tomita Y., Horio T., Narusaka Y., Nakazawa Y., Nishiumura K., Iwamoto S., 1999. Induced resistance of acibenzolar-S-methyl (CGA 245704) to cucumber and Japanese pear diseases. Eur. J. Plant Pathol. 105, 77-85.

Lawton, K.A., Friedrich, L., Hunt, M., Weymann, K., Delaney, T., Kessmann, H., Staub, T., Ryals J., 1996. Benzothiadiazole induces disease resistance in Arabidopsis by activation of the systemic acquired resistance signal transduction pathway. Plant J. 10, 71-82.

Lee, I.M., Hammond, R.W., Davis, R.E., Gundersen, D.E., 1993. Universal amplification and 388 analysis of pathogen 16SrDNA for classification and identification of mycoplasma-like organisms. Phytopathology 83, 834-842.

Lee, I.M., Gundersen, D.E., Hammond, R.W., Davis, R.E., 1994. Use of mycoplasma-like organism (MLO) group-specific oligonucleotide primers for nested-PCR assays to detect mixed MLO infection in a single host plant. Phytopathology 84, 559-566.

Maleck, K., Dietrich, R.A., 1999. Defense on multiple fronts: how do plants cope with diverse enemies? Trends in Plant Sci. 4, 215-219.

Marzachì, C., Bosco D., 2005. Relative quantification of chrysanthemum yellows (16Sr I) phytoplasma in its plant and insect host using real-time PCR. Mol. Biotechnol. 30, 117-127.

Morone, C., Boveri, M., Giosue, S., Gotta, P., Rossi, V., Scapin, I., Marzachi, C., 2007. Epidemiology of Flavescence doree in vineyards in northwestern Italy. Phytopathology 97, $1422-1427$.

Muñiz, M.; Nombela, G.; Saygili, H.; Sahin, F.; Aysan, Y., 2009. Research on tomato resistance to the virus-transmitter whitefly Bemisia tabaci undertaken during the last years in Madrid (Spain). Acta Hortic., 808, 175-179.

Nombela, G.; Pascual, S.; Aviles, M.; Guillard, E.; Muñiz, M., 2005. Benzothiadiazole induces local resistance to Bemisia tabaci (Hemiptera: Aleyrodidae) in tomato plants. J. Econ. Entomol. 98 (6), 2266-2271. 
Oostendorp, M., Kunz, W., Dietrich, B., Staub, T., 2001. Induced disease resistance in plants by chemicals. Eur. J. Plant Pathol. 107, 19-28.

Perez, L., Rodriguez, M. E., Rodriguez, F., Roson, C., 2003. Efficacy of acibenzolar-S-methyl, an inducer of systemic acquired resistance against tobacco blue mould caused by Peronospora hyoscyami f. sp. tabacina. Crop Protection 22, 405-413.

Pieterse C.M.J., Van Loon L.C., 2007. Signalling cascades involved in induced resistance. In: Walters, D., Newton, A., Lyon, G. (Eds.), Induced resistance for plant disease control: a sustainable approach to crop protection. Blackwell Publishing, Oxford, UK, pp.65-88.

Raupach, G.S., Murphy, J.F., Kloepper, J.W., 1995. Biological control of cucumber mosaic cucumovirus in Cucumis sativus L., by PGPR-mediated-induced systemic resistance. Phytopathology 85, 1167.

Romanazzi G., D’Ascenzo, D., Murolo, S., 2009. Field treatment with resistance inducers for the control of grapevine bois noir. J. Plant Pathol. 91, 677-682.

Saracco P., Marzachì C., Bosco D., 2008. Activity of some insecticides in preventing transmission of chrysanthemum yellows phytoplasma ('Candidatus Phytoplasma asteris') by the leafhopper Macrosteles quadripunctulatus Kirschbaum. Crop Protection 27, 130-136.

Schurter, R., Kunz, W., Nyfeler, R., 1987. Process and a composition for immunizing plants against diseases. US Patent 4931581.

Seemüller, E., Marcone, C., Lauer, U., Ragozzino, A., Gőschl, M., 1998. Current status of molecular classification of the phytoplasmas. J. Plant Pathol. 80, 3-26.

Vallad, E.G., Goodman, R.M., 2004. Systemic acquired resistance and induced systemic resistance in conventional agriculture. Crop Science 44, 1920-1934.

Vorwohl, G., 1977. The importance of the grapevine as a pollen plant for the honeybee. Apidologie, 8 (3), 237-257.

Walsh, K.B., Guthrie, J.N., White, D. T., 2006. Control of phytoplasma diseases of papaya in Australia using netting. Australasian Plant Pathol. 25, 49-54. 
432 Waetermeulen, X., van Girard, D., Legras, S., 1999. Influence on mite fauna of applications 433 targeted against the flavescence doree vector, Scaphoideus titanus (Ball). in vineyards. In: 434 Proceedings of the Fifth International Conference on Pests in Agriculture, Part 2, Montpellier, 435 France, 7-9 December 1999, pp. 409-416.

436 Weintraub, P.G., Beanland, L., 2006. Insect vectors of phytoplasmas. Ann. Rev. Entomol. 51, 91437 111.

438 YuHong, L., Peng, C., ZhiHui, C., HuiFang, D., 2006. Induction of resistance to downy mildew by 439 oxalic acid or $\mathrm{BTH}$ in cucumber seedlings and the accumulation of pathogenesis-related proteins in intercellular fluids. Acta Phytopathol. Sinica 36, 238-243. 
442 Table 1. CYP concentration in BTH-treated and control daisy plants expressed as the mean \pm 443 standard error (SE) of cells per ng of plant DNA. Plants were sampled at six, 11, 13 and 20 dpi. $n=$ 444 sample size. Within rows, values followed by the same letter do not differ significantly $(P<0.05)$. 445

\section{CYP $\quad$ BTH + CYP}

dpi mean cells/ng plant DNA \pm SE (n) mean cells/ ng plant DNA \pm SE (n)

\begin{tabular}{lll}
\hline $\mathbf{6}$ & $5.17 \times 10^{3} \pm 1.05 \times 10^{3}(7) \mathrm{a}$ & $2.43 \times 10^{3} \pm 3.17 \times 10^{2}(7) \mathrm{b}$ \\
\hline $\mathbf{1 1}$ & $1.56 \times 10^{5} \pm 2.5 \times 10^{4}(12) \mathrm{a}$ & $8.45 \times 10^{4} \pm 1.93 \times 10^{4}(10) \mathrm{b}$ \\
\hline $\mathbf{1 3}$ & $1.38 \times 10^{5} \pm 2.53 \times 10^{4}(12) \mathrm{a}$ & $6.88 \times 10^{4} \pm 1.61 \times 10^{4}(11) \mathrm{b}$ \\
\hline $\mathbf{2 0}$ & $2.96 \times 10^{5} \pm 4.29 \times 10^{4}(11) \mathrm{a}$ & $2.02 \times 10^{5} \pm 1.51 \times 10^{4}(9) \mathrm{a}$
\end{tabular}

446

447

448

449

450 
$451 \quad$ Figures captions

452 Figure 1. CYP symptom severity observed in the preliminary experiments in BTH-treated and 453 control plants. Symptoms were observed from 11 until 32 dpi on 20 plants at each observation date.

454 Figure 2. Proportion of CYP-infected daisy plants observed in the five experiment repeats on 2.4 455 mM BTH-treated and control plants.

456 Figure 3. CYP symptom severity recorded on $2.4 \mathrm{mM}$ BTH-treated and control plants observed 457 from 11 until 32 dpi. Asterisks indicate significant differences between the two plant treatments 458 according to the $t$ test. Fifty plants were observed at each dpi. 459 


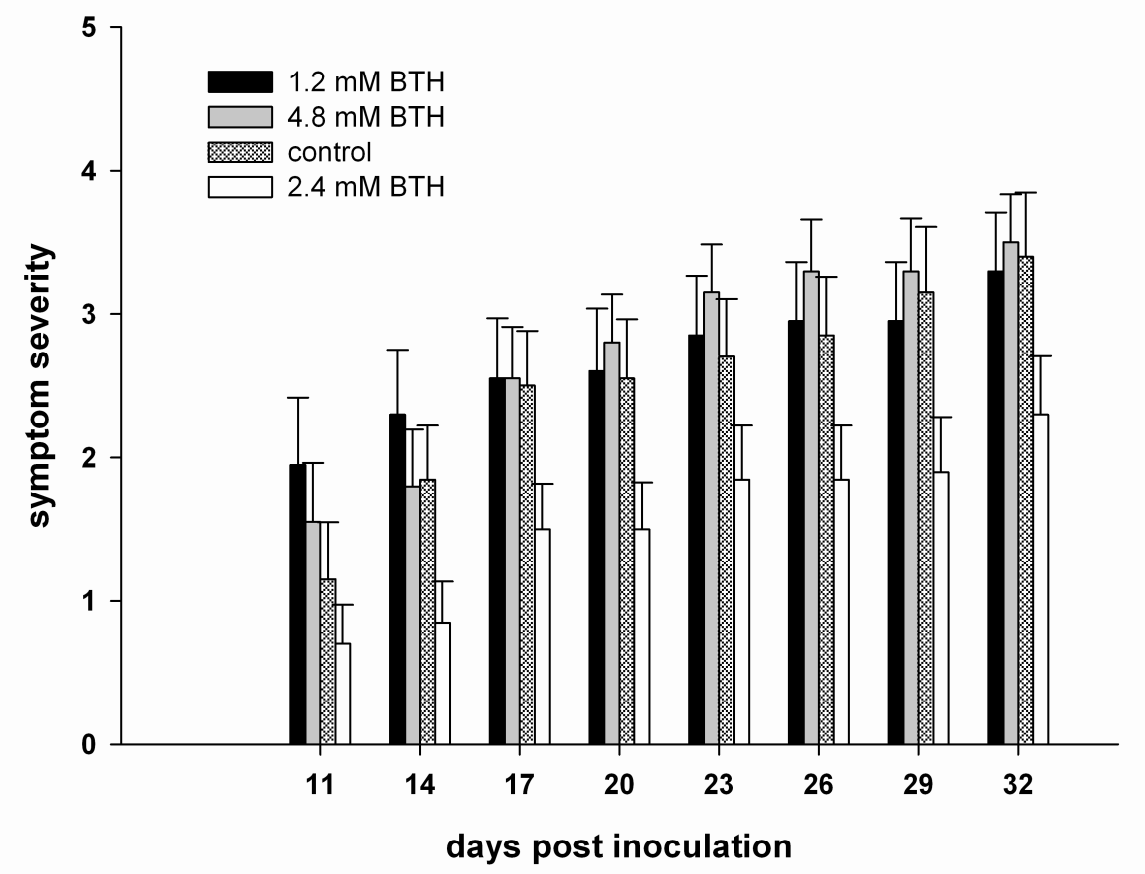




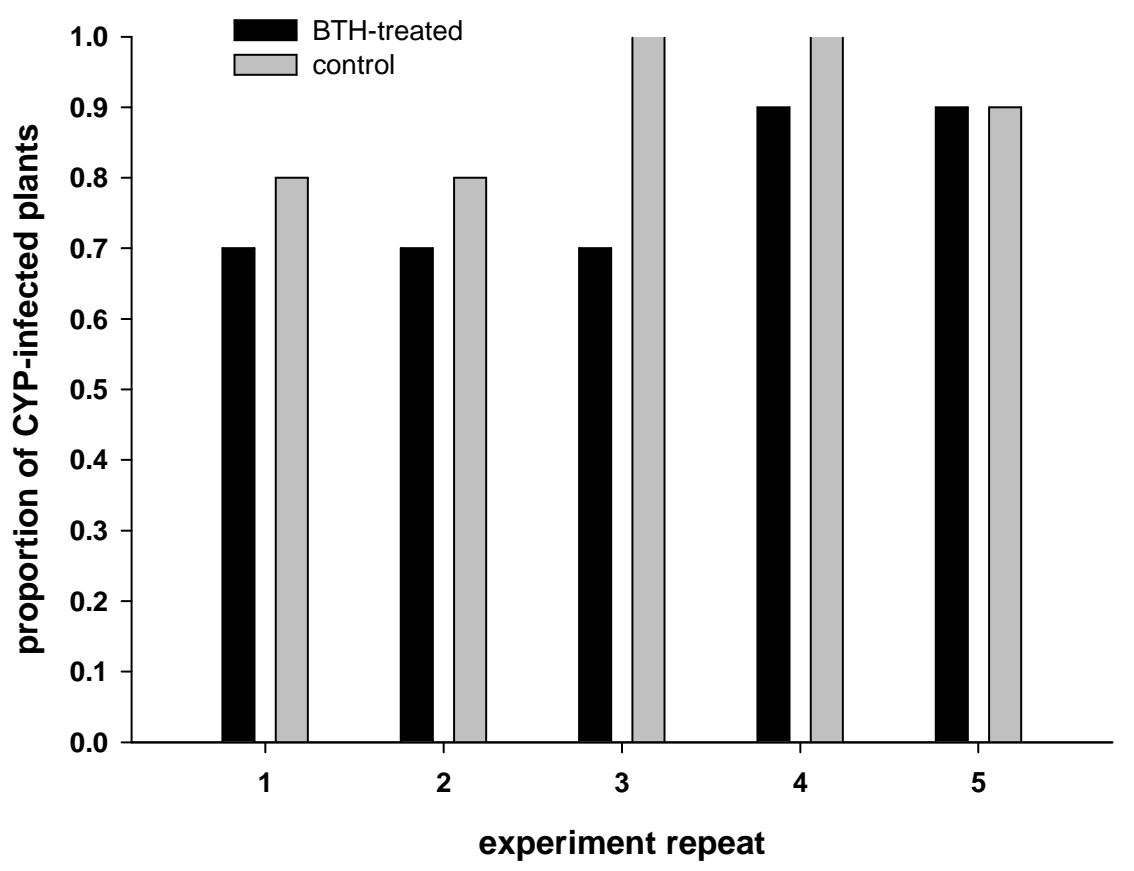




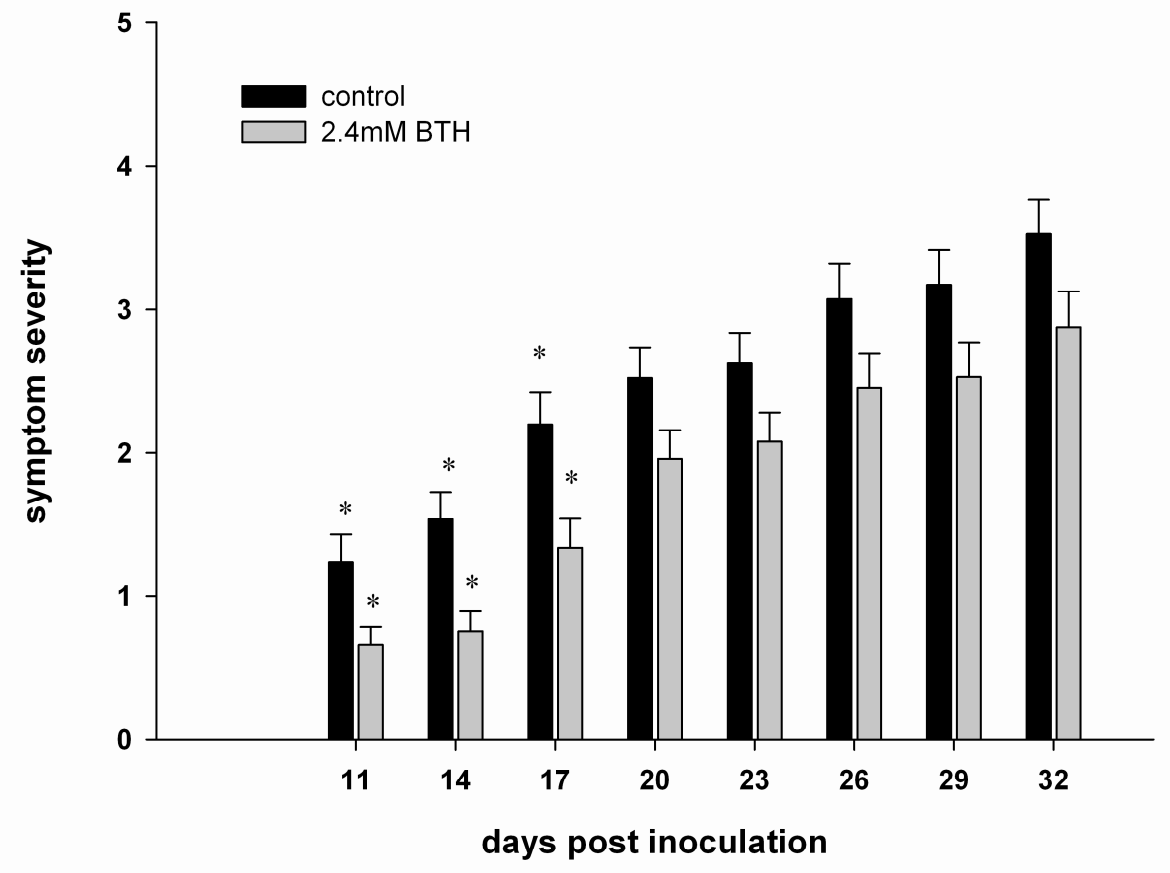

464 